НАУКОВИЙ ВІСНИК

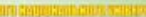

tanimail

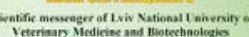

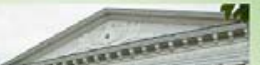

ก71711

(I) 11 is

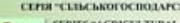
Toм 21 Ni 90

2019
Науковий вісник Дьвівського національного університету ветеринарної медицини та біотехнологій імені С.3. Гжицького. Серія: Сільськогосподарські науки

Scientific Messenger of Lviv National University of Veterinary Medicine and Biotechnologies.

Series: Agricultural sciences

ISSN 2519-2698 print

https://nvlvet.com.ua/index.php/agriculture

doi: $10.32718 /$ nvlvet-a9003

UDC 637.5.04/.07:636.4[575.181+575.1]

\title{
Quality of meat and bacon of signs of swine breeds of landrace of different status and genotype
}

\section{T.V. Shevchuk}

Vinnytsia National Agrarian University, Vinnitsa, Ukraine

Article info

Received 21.01.2019

Received in revised form 23.02.2019

Accepted 25.02.2019

Vinnytsia National Agrarian University, Sonyachna Str., 5 Vinnitsa, 21008, Ukraine. Tel.: +38-067-95-04-388 E-mail: tatjana.melnikova@ukr.net
Shevchuk, T.V. (2019). Quality of meat and bacon of signs of swine breeds of landrace of different status and genotype. Scientific Messenger of Lviv National University of Veterinary Medicine and Biotechnologies. Series: Agricultural sciences, 21(90), 14-20. doi: 10.32718/nvlvet-a9003

Livestock breeding has a number of technological features. They are related to the specific properties of the object of cultivation - animals. In order to obtain high-quality animals, high-quality products must take into account their genetic features. For example, in pigs, the quality of meat, fat, smoked pork determines the breed of animals, their sex, age and the direction of cultivation. Therefore, the study of the impact of sex and genotype on the productivity of pigs is relevant and practically valuable. There are many literature on the quality of pork animals of various breeds: Landrace, Durok, Great White and others. Scientists note that the best bacon and meat qualities are pigs of pores Landrace. However, scientific literature knows little about the way the sex and origin of animals affect the quality of meat and bacon in these pigs. Therefore, the purpose of our research was to study the slaughter, the qualities of bacon, the physico-chemical indicators of meat and fat females and castrated male species of landraces of two lines List and Brom. During the experiment, zootechnical, statistical, biometric, biochemical methods of research were used. Scientific research was carried out in the complex of fattening and slaughter of the shop of a private enterprise. During the experiment, it was found that the mass of pigs after slaughter, the mass of carcasses and the yield of carcasses of females and castrated males of both lines did not differ. However, the visceral fat content was higher in women by 1.24-8.98\% than in men. The properties of the pigs of both sexes were the same. However, in the male line of Brom, the width of the rear half of the carcass was $15 \%$ higher than that of women. The assessment of the quality of meat showed that females on both lines dominated by males for the content of fat, marble and calories. It has been experimentally established that the quality parameters of adipose tissue of Landrace have sex differences in the lines List and Brom. It was established that the water content in adipose tissue in women was lower in comparison with men by $0.5-2.35 \%$, the fat was higher than $0.37-3.25 \%$, the iodine number was 3.43-3.68 units. Our research can be recommended to companies that specialize in pig breeding. If a company breeds animals for processing into bacon or smoked, it is advisable to grow a breed from the Brom line. In this case, the best ham can be obtained from castrated males, and juicy, tender meat and more fatty tissue - in females.

Key words: pig breeding, landrace breed, signs of bacon, quality of meat, sex, lines.

\section{Якість м'яса та беконі ознаки свиней породи ландрас різної статі та генотипу}

\author{
Т.В. Шевчук
}

Вінницький національний аграрний університет, м. Вінниця, Украӥна

Якість м'яса свиней визначається рядом типових та атипових ознак. Серед них генотип є визначальним. За допомогою вмілої селекиійної роботи з поголів'ям свиней можна одержати свинину бажаних ознак. Тому метою наших досліджень було вивчити вплив гендерних та спадкових факторів ландрасів на якість м'яса та беконні ознаки. Об'єктом дослідження в наші роботі були продуктивні ознаки свиней породи ландрас різної статі. Предметом вивчення були: забійні, беконні та м'ясні ознаки самок і кастрованих самиів різного генотипу. В ході досліджень було установлено, щзо свинки та кнуриі породи ландрас ліній Ліста та Брома 
суттєво не відрізнялися за забійними показниками. Однак, самки лінії Ліста мали більще вісиерального жиру в порівнянні з тваринами лінії Брома на 7,72\%. Беконні ознаки свиней породи ландрас не мали гендерної залежності, проте у кнуриів лінї̈ Брома иирина задньої частини напівтуші була на 15,43\% більшою, ніж у свинок. Фізико-хімічні параметри м'яса свиней породи ландрас обох статей суттєво не вірізнялись. Проте, в розрізі ліній установлено, щуо у свинок лінії Брома вміст жиру був на 6,05\% вище, ніж у кнуриів, показник мармуровості - на 49,5 одиниці, а калорійність - на 72,79 кілокалорій. Крім того, установлені якісні зміни у хімічному складі і властивостях жирової тканини свинок і кнуриів вказаної породи.

Ключові слова: свинарство, порода ландрас, продуктивність, стать, лінії.

\section{Introduction}

In the world there are more than 100 breeds of pigs, and taking into account local, local and disappearing 400 . In the developed countries of the world use only 1015 breeds of meat production direction. In Ukraine, the most common domestic breeds are the Ukrainian steppe, the big white and Mirgorod breed, and among the foreign - Landras and Durok (Berezovs'kyi, 2000; Misik, 2014).

Landrace is one of the most popular and widespread breeds in the world and most suitable for meat fattening. On the basis of this breed, there are populations of Belgian, French, American, Canadian, Swedish, Finnish, Ukrainian and other breeds that are similar in terms of constitution, exteriors and type of productivity. The largest number of pigs in the Landrace was in $1980-130$ thousand heads, including 20 thousand main ducks and boars, they belonged to 8th place among other breeds. The new Ukrainian plant type has 20.000 heads, including 930 main lambs and 107 boars. Annually used 1632-1777 heads of kennel-breeders, including breeding enterprises 67-89 goals (Fedorenkova, 2005; Topiha et al., 2008).

Landrace is well adapted to a variety of feeding, well consumes and uses substances of plant and animal origin, and also have the increased ability to transform feed into meat. However, these animals are susceptible to lack of essential amino acids in rations (methionine, lysine, tryptophan and others) and vitamins of group B, so balanced nutrition is important for them (Aaslyng \& Meinert, 2017).

From a physiological point of view, the Landrace has a larger proportion of meat in the carcass and better developed internal organs than other breeds, increased protein metabolism and more intensive muscle tissue. Even with a live weight of $120 \mathrm{~kg}$, the meat content of the carcass exceeds $60 \%$. Landrace more efficiently absorbs nitrogen in feeds, they have a better ratio of protein to fat, and they have higher protein content than the chemical properties of meat and are slightly inferior to the physical properties of large white breeds (Franco \& Lorenzo, 2013; Topiha, 2014).

The breed is widely used as a parent in crossover breeding and hybridization. Despite the fact that animals reproduce earthly varieties for over 100 years, they are now continuing to improve and study the features of nutrition, breeding and breeding work. However, the gender characteristics of the Landrace, their fertility and quality of meat are not fully understood, so the purpose of the dissertation is to study these characteristics in this breed, depending on gender and genotype. Therefore, an indepth and comprehensive study of the mechanism of influencing these factors on the quality of products derived from pigs, in particular bacon, meat and fat, is relevant.
Literature review. The main features that largely determine the economy of pigs include the fattening and meat quality of pigs. Numerous scientific studies and practical observations have found that animals of the same breed, which are in the same conditions of feeding and maintenance, differ significantly among themselves for the speed and efficiency of the transformation of consumed feed (Bodrjashova, 2015; Vojtenko, 2015).

The following characteristics are attributed to the fattening qualities of young pigs: age of achievement of live weight of $100 \mathrm{~kg}$, days; average daily increment in fattening, g; feed costs per $1 \mathrm{~kg}$ increase, feed unit. With full feeding and satisfactory maintenance of the substrate, the landrace and the land in the 6-7 months of age reach a live weight of $100-120 \mathrm{~kg}$, in connection with which the advanced specialized farms produce on the basis of each animal in the herd, taken at the beginning of the year, 150 $\mathrm{kg}$ of commercial pork, or $15-25$ ts in live weight per sow (Voloshhuk, 2013).

Average daily increments of the pigs are significantly different: Poltava breed 690-870 g, Ukrainian beef breed 784 g, Landrace 700-750 g, Duroc 750-800 g, Welsh breed $750 \mathrm{~g}$ (Tsereniuk et al., 2016).

Landrace pork is different from other farm animals. Under optimal conditions, for $1 \mathrm{~kg}$ of live weight gain, 4 5 feeds are used. unit and less, as evidenced by numerous scientific studies and good practice in the industry; adult animals - 5-7 feeds (Strizhak, 2014; Alonso et al., 2015).

Signs that determine inheritance qualities have a fairly high inheritance $\left(\mathrm{h}^{2}\right)$. Its value, according to a number of authors, is based on the average daily increments in pigs of large white breed is 40-77, rocks of landraces - 36-45, breeds of Duroc and Berkshire - 24-45; at the expense of feed $-30-50$, respectively; $30-50$ and 20-34. Selection according to the phenotype reliably ensures the increase of this characteristic in the herd (Topiha et al., 2008; Alonso et al., 2015; Tsereniuk 2016).

Landrace is a large-breed type. The body of an adult boar in length can reach two meters, and the girth of the chest is more than 1.5 meters. Sows grow in length at an average of 1.5-1.7 m. An adult boar has a weight of 270$310 \mathrm{~kg}$, a sow - an average of $200 \mathrm{~kg}$. Despite a significant body mass, the animals are quite active, many move (Shavaljuk \& Popivnjak, 2014).

The quality of pork meat is estimated by the following indicators: slaughter weight; slaughter of the length of the chilled carcass; fat thickness; area of "muscle cell"; the mass of the rear half of the carcass. Slaughter mass is the mass of steam carcass with skin without head, limbs, internal fat and internal organs, in landraces it is 100$120 \mathrm{~kg}$ (Pauly et al., 2012).

Slaughter is the ratio of the mass of the carcass after processing to the live weight of the pig before slaughter. Depending on the age and fatness of the pigs, the breed 
and the type of fattening, this coefficient in the Landrace breed is $70-75 \%$, which is $20-25 \%$ higher than that of cattle and sheep. The largest index, which is specified in the special literature, is $88-90 \%$. When growing on bacon or meat it will be less (70-75\%), and at fattening to the state of fat $-80-82 \%$ and more. The number of bones in the carcass pigs landraces is less than 2.5 times (SánchezMacías et al., 2018).

The length of the chilled carcass is measured by a measuring tape in an upright position from the surface of the first cervical vertebra to the anterior margin of the pubic joint, in the Landsrace it reaches 90-100 cm (Nassu et al., 2017).

The thickness of the pin is measured by a millimeter ruler on a cooled hemisphere over 6-7 thoracic vertebrae. The thickness of the spike in different breeds of pigs is different. For example, in Poltava meat breed - 22 $28 \mathrm{~mm}$, Ukrainian beef - $24 \mathrm{~mm}$, rocks Landrace - 26-28 $\mathrm{mm}$, Duroc - 19-23 mm, Welsh breed - 20-22 mm (Vojtenko, 2015).

The area of the "muscle cell" is determined by the transverse incision of the longest back muscle between the first and second lumbar vertebrae, in the pigs Landrace Land it is 32-33 mm (Fernández-Dueñas et al., 2008).

The mass of the rear half of the cooled half of the carcass is part of the carcass separated by a transverse incision between the last and last transverse vertebrae, and in the pig breed landrace it reaches 10-12 kg (Polivoda, 1976).

One of the main attributes of pig production is speediness. Particularly important is this when fattening or growing, because the length of stay of young animals on fattening, growing, feeding costs and growth means is inversely proportional to speed. The efficiency of fattening depends on many factors, the main of which - the conditions of abstinence and feeding, race, age and live weight of animals. Numerous studies of domestic and foreign scientists have shown that under identical conditions of feeding and keeping the fattening qualities of pigs of different breeds and inferential combinations do not show the same (Vojtenko, 2015).

Scientists (Franco et al., 2014; Alonso et al., 2015; Guzek et al., 2016) found that the three-breed young, obtained by crossing the domestic moths of the Belarusian meat $\times$ Landrace with the rods of the Landrace and Duroc Canadian breeding had an age of reaching a live weight of $100 \mathrm{~kg}$, respectively, 177.2 and 179.5 days, and the costs feed for $1 \mathrm{~kg}$ of growth of 3.38-3.4 feed units, which is significantly higher than other studied genotypes. At the same time, when crossed by sows of a large white breed and Landrace of French origin with bunches of large white breed, Duroc, Landrace and Pigs breed Pitren of German breeding, the best offspring were the descendants of the Landrace rocks that dominated the peers of other genotypes by age reaching a living weight of $100 \mathrm{~kg}$ at 2.9-23.2 days (Fernández-Dueñas et al., 2008; Vojtenko, 2015; Imazaki et al., 2019).

In Ukraine, the landrace were introduced in 1960 from Canada, Sweden, England, and the Russian Federation. Animals are well acclimated, characterized by high reproductive and meat-salty qualities. Genealogical structure of breed in breeding farms of Ukraine is represented by 19 plant lines and 21 families. The most widespread are in
Kharkiv, Kyiv, Ternopil, Mykolayiv and other oblasts (Topiha et al., 2008).

The main features that determine the economy of pig breeding include fattening and meat quality of pigs. Assessment of the quality of pig meat is very important and is of considerable scientific interest. The quality of fattening pigs is determined by the speed, average daily increment, feed costs per unit of increment, as well as the ultimate economic efficiency. Check the fattening qualities of pigs by means of control fattening.

Meat productivity is determined by the quantity of products derived from pigs, suitable for use in food. Rate it on the slaughter mass, the mass of carcasses and the output of meat in the carcass. The length of the carcass of the Landrace pig breed is $90(q)$ and $100(\delta) \mathrm{cm}$, the thickness of the pig breed is 6-7 thoracic vertebrae - 26 (ठ) $\mathrm{mm}$ and 28 (ㅇ) $\mathrm{mm}$, the area of the "muscle cell" is almost the same in females and males is $32-33 \mathrm{~cm}^{2}$, the output of muscle tissue is $60(\%) \%$ and $63(3) \%$, the weight of the ankle is up to 10 () $\mathrm{kg}$ and 12 (ङ) $\mathrm{kg}$ (Juárez et al., 2011).

The long-term selection of Landraces to increase their fattening qualities and meat productivity, increasing the length of the trunk led to the formation of some morphological and physiological features in animals, which distinguish them from the representatives of the roots of sebaceous and meat-fatty types. By the content of protein in meat (and the energy contained therein), the Landrace pig breeds surpass the pigs of large white breeds at 6 months of age by $21.1 \%$, and in the 9 -month-old by $26.6 \%$. Contents of energy per $1 \mathrm{~kg}$ of live weight in the undergrowths of the Landrace breed inferior to large a breed, which suggests a more intense protein synthesis in the Landrace pigs (Klauke et al., 2013).

Landrace is of interest to the research work of scientists. It was established that pigs of this breed have more relative weight and better developed internal organs than other animals of other breeds. The further direction of breeding work is aimed at increasing the fattening and meat qualities, according to the results of their own productivity (Li et al., 2013; Vojtenko, 2015).

Consequently, for many years the landrace breed has been improved for reproduction, but mainly for meat qualities. The long-term selection for increasing their fattening qualities, meat productivity and increasing the length of the trunk led to the formation in animals of some morpho-physiological features that distinguish them from representatives of the roots of sebaceous and meatand-fatty types. It has been experimentally established that females and males of this breed have certain differences in productive indices, the formation of muscle and adipose tissue, and their biochemical composition. A number of combinations of crossbreds of the rocks of the Landrace breed with stems of domestic breeds are studied. However, certain breeding, meat and morphological and functional features of swine breeds of Landraces of different sexes and lines are not considered.

Material and methods. The purpose of the experiment was to investigate the productive features of pigs of Landrace breed of different sexes of selected parental lines based on the private enterprise "AGROPROM +" of Florin village of Bershad district of Vinnitsa region. The 
object of the research is the productive signs of swine of the landraces of different sexes. The subject of the study was fattening, slaughter, meat and bacon animals according to gender differences, taking into account breeding. To accomplish this goal, the following tasks were planned: to conduct a scientific and economic experiment, to study the bacon signs of swine of the landraces of different sex and origin, to study the physical and chemical parameters of meat and fatty tissue.
The research was conducted in the private enterprise "AGROPROM+" in the village of Florine, Bershad district, Vinnitsa region. In order to accomplish the tasks set in the farm on the principle of analogues, the young pigs of the breed of landraces of the two lines of List and Brom (and one Daghi family) of both sexes were selected and raised to slaughter conditions. The experimental scheme is presented in Table 1.

Table 1

Scheme of experiment *

\begin{tabular}{|c|c|c|c|c|c|}
\hline \multirow[b]{2}{*}{ Group } & \multirow[b]{2}{*}{ Sex } & \multirow{2}{*}{$\begin{array}{l}\text { Number of } \\
\text { animals in the } \\
\text { group (n) }\end{array}$} & \multirow[b]{2}{*}{ Breed, genotype } & \multicolumn{2}{|c|}{ Live weight, kg: } \\
\hline & & & & $\begin{array}{c}\text { when staged on an } \\
\text { experiment }\end{array}$ & $\begin{array}{c}\text { at the end of the } \\
\text { experiment }\end{array}$ \\
\hline I & $\begin{array}{c}\text { castrated males } \\
\left(\delta^{\pi}\right)\end{array}$ & 10 & Landrace (Liszt Line) & 40 & 100 \\
\hline II & female (ㅇ) & 10 & Landrace (Liszt Line) & 40 & 100 \\
\hline III & $\delta$ & 10 & Landrace (Brom line) & 40 & 100 \\
\hline IV & 우 & 10 & Landrace (Brom line) & 40 & 100 \\
\hline
\end{tabular}

In order to study the slaughter quality of swine, the landraces of different sex and genotype were slaughtered in 4 animals from each group to achieve their mortality. The following indicators were determined: mass of carcass, slaughter output, carcass output, length of half a bacon, thickness of fat over 6-7 thoracic vertebrae. To study the bacon qualities of the Landraces breed of pig of different lines took into account: the mass of the cooled half-carcass, the length of the half of carcase and the bacon halves, the width of the anterior and posterior parts of the bacon halves, the area of the muscular cell according to generally accepted techniques. Indicators of meat and fat production of experimental animals were determined according to the methods of AM Polivod, RV Strobinina, MD Lyubetskii (Polivoda, 1976), the recommendations of VASGNIL and the Pork Institute. O.V. Kvasytskyi NAANU (Voloshhuk, 2013).

The digital material was statistically processed by N.A. Plokhinsky (Plohinskij, 1969). The received digital data was processed using the program MS EXEL 2007, statistically estimated according to Student's criterion $(\mathrm{t})$. Results were considered statistically significant at $\mathrm{P}<0.1$ (differences found at the level of the statistical trend), $\mathrm{P}<0.05$ (statistically significant differences were found), $\mathrm{P}<0.01$ (differences found at high level of statistical significance), $\mathrm{P}<0.001$ (differences are found at almost absolute level of statistical significance). In the table material the following symbols are taken: td $-\mathrm{P}<0.1$, $* \mathrm{P}<0.05, * * \mathrm{P}<0.01, * * * \mathrm{P}<0.001$.

\section{Results and discussion}

It has been scientifically proven that the higher the slaughter output in animals, the greater the carcass meatiness and the output of individual slaughter products (Topiha et al., 2008; Voloshhuk, 2013). The results of the study of slaughter pigs of the Landrace species of the two Listed and Brom lines are presented in Table 2.

\section{Table 2}

Quality of slaughter products of swine, depending on sex, $M \pm m(n=4)$

\begin{tabular}{|c|c|c|c|c|}
\hline \multirow{2}{*}{ Indicator } & \multicolumn{2}{|c|}{ Landrace (Liszt line) } & \multicolumn{2}{|c|}{ Landrace (Brom line) } \\
\hline & castrated males $\left(\delta^{\lambda}\right)$ & female ( $(+)$ & castrated males $\left(0^{1}\right)$ & female (ㅇ) \\
\hline Weight before slaughter, kg & $101.5 \pm 3.11$ & $95.13 \pm 0.25^{\mathrm{td}}$ & $104.38 \pm 1.89$ & $100.13 \pm 2.02$ \\
\hline Mass of carcass, $\mathrm{kg}$ & $71.31 \pm 2.53$ & $66.23 \pm 10.86$ & $73.89 \pm 2.43$ & $69.59 \pm 1.34$ \\
\hline Slaughter output, $\%$ & $70.25 \pm 10.95$ & $69.63 \pm 0.75$ & $70.90 \pm 1.06$ & $69.51 \pm 0.41$ \\
\hline $\begin{array}{l}\text { The thickness of the pin is at } \\
\text { the level } 6-7 \text { of the thoracic } \\
\text { vertebra, } \mathrm{mm}\end{array}$ & $19.40 \pm 0.86$ & $20.03 \pm 0.53$ & $18.63 \pm 0.75$ & $19.50 \pm 0.41$ \\
\hline
\end{tabular}

From the table material, it becomes clear that List's piglets after hunger had less weight before slaughter compared to the buds at $6.37 \mathrm{~kg}(\mathrm{P}<0.1)$. Perhaps such differences are due to faster evacuation of the contents of the gastrointestinal tract in the pigs in a slightly shorter intestine than in animals of the opposite sex. Other researched indicators did not have statistically significant differences. However, the pigs were characterized by a thickness of $0.63 \mathrm{~mm}$ (Liszt), but $0.87 \mathrm{~mm}$ (Bromine line) in the male pigs, while the highest was Liszt's line. The explanation for this, in our opinion, is the best lipid metabolism of the animals of this line and the predominance of liponeogenesis processes. A confirmation is made of the analysis of the output of slaughter products (Table 3 ).

From the given material it can be seen that the pigs of 
the rocks of the landraces of both lines were dominated by snags after the release of internal fat (by $168.0 \mathrm{~g}$ in the
List line $(\mathrm{P}<0.05)$ and $25.00 \mathrm{~g}$ in the Broms line $(\mathrm{P}<0.1)$.

\section{Table 3}

Output of products of slaughter of the pigs of the Landrace species, depending on sex, $M \pm m(n=4)$

\begin{tabular}{|c|c|c|c|c|}
\hline \multirow{2}{*}{ Indicator } & \multicolumn{2}{|c|}{ Landrace (Liszt Line) } & \multicolumn{2}{|c|}{ Landrace (Brom line) } \\
\hline & castrated males $\left(0^{\lambda}\right)$ & female () & castrated males $\left(0^{\lambda}\right)$ & female $(+)$ \\
\hline Liver, $\mathrm{g}$ & $1025.0 \pm 117.54$ & $980.0 \pm 146.74$ & $1062.5 \pm 62.92$ & $971.25 \pm 25.29$ \\
\hline $\begin{array}{l}\text { Output of offal, } \% \text { to the } \\
\text { weight of the animal before } \\
\text { slaughter }\end{array}$ & 1,01 & 1,03 & 1,02 & 0,97 \\
\hline Kidney, g & $326.25 \pm 20.56$ & $314.5 \pm 24.24$ & $337.50 \pm 18.48$ & $303.75 \pm 13.77$ \\
\hline Output of offal, $\%$ & 0,32 & 0,33 & 0,32 & 0,30 \\
\hline Spleen, $g$ & $180.0 \pm 20.41$ & $134.5 \pm 11.45$ & $138.25 \pm 6.24$ & $112.5 \pm 9.57$ \\
\hline $\begin{array}{l}\text { Output of the slaughter } \\
\text { product, } \%\end{array}$ & 0,18 & 0,14 & 0,13 & 0,11 \\
\hline Spleen, $g$ & $671.25 \pm 16.52$ & $626.25 \pm 18.87$ & $692.5 \pm 16.5$ & $676.25 \pm 20.56$ \\
\hline Output of offal, $\%$ & 0,66 & 0,66 & 0,66 & 0,68 \\
\hline Visceral fat, $\mathrm{g}$ & $1837.5 \pm 184.28$ & $2002.5 \pm 106.5^{*}$ & $2013.75 \pm 130.73$ & $2038.8 \pm 163.32^{\mathrm{td}}$ \\
\hline Fat output, $\%$ & 1,81 & 2,11 & 1,93 & 2,04 \\
\hline Heart, d & $325.0 \pm 13.54$ & $305.0 \pm 12.25$ & $351.25 \pm 24.62$ & $312.5 \pm 6.45$ \\
\hline Output of offal, $\%$ & 0,32 & 0,32 & 0,34 & 0,31 \\
\hline
\end{tabular}

Landrace pigs relate to the bacon growing direction, so the evaluation of their bacon characteristics is important for livestock production technology. The results of the study of such indicators in pigs of the specified breed, depending on sex, are given in Table 4.

The presented material shows that the length of the half of carcass, the bacon halves, the width of the front of the bacon and the area of the "muscle cell" of the pigs and bud of both lines did not have any significant differences. However, in the Brom line, the width of the rear of the bacon halves was $15.43 \%$ higher, while the differences revealed a tendency to be reliable $(\mathrm{P}<0.1)$.

Bacon is valued for its nutritional and flavoring properties, which are determined by the content and ratio of muscle and adipose tissue. Therefore, the study of the physico-chemical indicators of the latter is very important for determining the quality of the main product of bacon pig breeding. We have been investigating the physicochemical indices of pig breeds of landraces of different sexes. The results of these studies are presented in Table 5 .

\section{Table 4}

Bacon qualities of swine of the Landrace genus, depending on sex, $M \pm m(n=4)$

\begin{tabular}{|c|c|c|c|c|}
\hline \multirow[b]{2}{*}{ Indicator } & \multicolumn{2}{|c|}{ Landrace (Liszt Line) } & \multicolumn{2}{|c|}{ Landrace (Brom line) } \\
\hline & $\begin{array}{c}\text { castrated males } \\
(0)\end{array}$ & female (ㅇ) & castrated males $(\overbrace{}^{\Uparrow})$ & female (q) \\
\hline Length of carcass, centimeters & $95.4 \pm 4.71$ & $89.0 \pm 0.91$ & $96.25 \pm 1.85$ & $95.00 \pm 2.58$ \\
\hline The length of half a bacon, centimeters & $77.43 \pm 2.94$ & $70.70 \pm 5.20$ & $76.03 \pm 2.69$ & $73.25 \pm 2.84$ \\
\hline $\begin{array}{l}\text { Width of the front half of half a bacon, } \\
\text { centimeters }\end{array}$ & $37.90 \pm 1.07$ & $36.50 \pm 4.38$ & $36.25 \pm 1.85$ & $35.00 \pm 2.58$ \\
\hline $\begin{array}{l}\text { The width of the rear half of the bacon, } \\
\text { centimeters }\end{array}$ & $27.83 \pm 1.77$ & $22.63 \pm 2.66$ & $30.88 \pm 0.85$ & $26.75 \pm 1.94^{\text {td }}$ \\
\hline The area of the "muscular eye", $\mathrm{cm}^{2}$ & $37.20 \pm 2.92$ & $32.88 \pm 2.21$ & $38.25 \pm 1.66$ & $35.83 \pm 3.14$ \\
\hline
\end{tabular}

\section{Table 5}

Indices of landrace pigs meat, depending on sex, $M \pm m(n=4)$

\begin{tabular}{|c|c|c|c|c|}
\hline \multirow{2}{*}{ Indicator } & \multicolumn{2}{|c|}{ Landrace (Liszt Line) } & \multicolumn{2}{|c|}{ Landrace (Brom line) } \\
\hline & castrated males $\left(\delta^{\wedge}\right)$ & female $(+)$ & castrated males $\left(ठ^{\lambda}\right)$ & female $(+)$ \\
\hline $\mathrm{pH}$, units & $5.53 \pm 0.1$ & $5.75 \pm 0.10$ & $5.65 \pm 0.10$ & $5.85 \pm 0.10$ \\
\hline $\begin{array}{l}\text { Color intensity, light ab- } \\
\text { sorption unit } \times 10^{-3}\end{array}$ & $52.28 \pm 1.59$ & $50.55 \pm 0.66$ & $53.85 \pm 2.75$ & $50.93 \pm 1.04$ \\
\hline Total moisture content, $\%$ & $73.45 \pm 1.51$ & $70.95 \pm 1.28$ & $73.78 \pm 1.41$ & $72.38 \pm 1.44$ \\
\hline Dry matter content, $\%$ & $26.55 \pm 1.51$ & $29.05 \pm 1.28$ & $26.2 \pm 1.32$ & $27.63 \pm 1.44$ \\
\hline Protein content, $\%$ & $21.43 \pm 0.99$ & $19.98 \pm 0.46$ & $21.83 \pm 0.40$ & $19.85 \pm 0.45$ \\
\hline Fat content, $\%$ & $4.33 \pm 2.89$ & $8.03 \pm 2.27$ & $5.23 \pm 2.30$ & $14.08 \pm 2.53 *$ \\
\hline Indicator of marble, units & 26.1 & 44.1 & 31.9 & 81.4 \\
\hline Caloric content, $\mathrm{kcal} / 100 \mathrm{~g}$ & 163.00 & 190.18 & 174.12 & 246.91 \\
\hline $\mathrm{MJ} / 100 \mathrm{~g}$ & 679.7 & 793.03 & 726.08 & 1029.59 \\
\hline
\end{tabular}


The material in the table shows that the biochemical composition of the muscle tissues of females and male breeds of the main types of the two lines did not have significant differences. The exception was the content of pig fat in the Brah line: in male pigs, the prevalence was $8.85 \%$, with a significant difference $(\mathrm{P}<0.05)$. An increase in fat content in meat has led to an increase in the index of marble of the muscle tissue of pigs by 18 units.
(List Line) and 49.5 units. (Bromide Line) and calories at 27.18 and $72.79 \mathrm{kcal} / 100 \mathrm{~g}$ or 113.33 and 303.51 MDL/100 g, respectively.

The study of the physicochemical properties of the adipose tissue of Landrace pigs has shown a tendency for significant changes in the content of moisture, dry matter and neutral lipids (NL) in the fat of females and males of the List line (Table 6).

\section{Table 6}

Physical and chemical parameters of adipose tissue of species of pigs Landrace, depending on sex, $M \pm m(n=4)$

\begin{tabular}{|c|c|c|c|c|}
\hline \multirow{2}{*}{ Indicator } & \multicolumn{2}{|c|}{ Landrace (Liszt Line) } & \multicolumn{2}{|c|}{ Landrace (Brom line) } \\
\hline & castrated males $\left({ }^{\lambda}\right)$ & Female $(q)$ & castrated males $\left(0^{\lambda}\right)$ & Female $(q)$ \\
\hline Total moisture content, $\%$ & $9.73 \pm 1.13$ & $7.48 \pm 0.51^{\text {td }}$ & $7.20 \pm 1.61$ & $6.70 \pm 0.57$ \\
\hline Dry matter content, $\%$ & $90.28 \pm 1.13$ & $92.53 \pm 0.51^{\text {td }}$ & $92.8 \pm 1.61$ & $93.3 \pm 0.57$ \\
\hline Fat content $(\mathrm{NL}), \%$ & $87.18 \pm 1.45$ & $90.43 \pm 0.87^{\text {td }}$ & $90.58 \pm 1.60$ & $90.95 \pm 1.01$ \\
\hline $\begin{array}{l}\text { Iodine number of fat, } \mathrm{ml} \text { of } \\
\text { iodine }\end{array}$ & $55.6 \pm 1.32$ & $59.28 \pm 0.61^{*}$ & $55.30 \pm 1.13$ & $58.77 \pm 1.44^{\mathrm{td}}$ \\
\hline
\end{tabular}

Additionally, in the pigs in comparison with the pockets of the two analyzed lines, there was a significant increase in the iodine number of the fat by $6.6 \%(\mathrm{P}<0.05)$ and $6.3 \%(\mathrm{P}<0.1)$, respectively, in the Liszt and Brom lines.

Consequently, the analysis shows that there are significant differences in the productive characteristics of Landrace pigs, depending on sex.

\section{Conclusions}

The analysis of the production of slaughter products showed that Liszt piglets had a higher content of internal fat at $8.98 \%(\mathrm{P}<0.05)$, and the bromine line was $1.24 \%$ $(\mathrm{P}<0.1)$.

Study of bacon quality in pigs did not reveal significant differences in sex, but in the Brom line, the width of the rear half of the bacon was $15.43 \%(\mathrm{P}<0.1)$ higher than in the pig.

Study of the physical and chemical properties of pigs in the two studied lines showed no significant changes, but in females, the fat content exceeded $6.05 \%$ of males $(\mathrm{P}<0.05)$, which led to an increase in the marble index by 49.5 units. and caloric content - at $72.79 \mathrm{kcal} / 100 \mathrm{~g}$.

Physico-chemical parameters of adipose tissue have gender differences in the two studied lines: the moisture content of women in women was less than in men by 0.5 $2.35 \%(\mathrm{P}<0.1)$, fat - more than 0,37-3,25\%, $(\mathrm{P}<0.1)$, and the iodine number is the highest $-3.43-3.68$ units $(\mathrm{P}<0.05)$.

\section{References}

Aaslyng, M.D., \& Meinert, L. (2017). Meat flavour in pork and beef - From animal to meal. Meat Sci, 132, 112-117. doi: 10.1016/j.meatsci.2017.04.012.

Alonso, V., Muela, E., Gutiérrez, B., Calanche, J.B., Roncalés P., Beltrán, J.A. (2015), The inclusion of Duroc breed in maternal line affects pork quality and fatty acid profile. Meat Sci, 107, 49-56. doi: 10.1016/j.meatsci.2015.04.011.

Berezovs'kyi, M.D. (2000). Svynarstvo Danii [Pig Production in Denmark]. Tvarynnyctvo Ukrainy, 7-8, 67 (in Ukrainian).

Bodrjashova, K.V. (2015). Produktivnist' svinej za riznih metodiv rozvedennay [Productivity of pigs for different breeding methods]. Rozvedennja i genetika tvarin, 50, 23-28 (in Ukrainian).

Fedorenkova, L.A. (2005). Vlijanie hrjakov nekotoryh importnyh porod na mjasnuju produktivnost' gibridnogo molodnjaka. [The effect of some imported breeds of boars on the meat productivity of young hybrids]. Zootehnicheskaja nauka Belarusi: sb. nauch. tr. Zhodino, 40, 128-132 (in Russian).

Fernández-Dueñas, D.M., Myers, A.J., Scramlin, S.M., Parks, C.W., Carr, S.N., Killefer, J., \& McKeith, F.K. (2008). Carcass, meat quality, and sensory characteristics of heavy body weight pigs fed ractopamine hydrochloride (Paylean). J Anim Sci, 86(12), 35443550. doi: 10.2527/jas.2008-0899.

Franco, D., \& Lorenzo, J.M. (2013). Effect of gender (barrows vs. females) on carcass traits and meat quality of Celta pig reared outdoors. J Sci Food Agric, 93(4), 727-734. doi: 10.1002/jsfa.5966.

Franco, D., Vazquez, J.A., \& Lorenzo, J.M., (2014). Growth performance, carcass and meat quality of the Celta pig crossbred with Duroc and Landrance genotypes. Meat Sci., 96(1), 195-202. doi: 10.1016/j.meatsci.2013.06.024.

Guzek, D., Głąbska, D., Głąbski, K., \& Wierzbicka, A. (2016). Influence of Duroc breed inclusion into Polish Landrace maternal line on pork meat quality traits. An Acad Bras Cienc., 88(2), 1079-1088. doi: 10.1590/0001-3765201620140679.

Imazaki, P.H., Elansary, M., Scippo, M.L., \& Daube, G. (2019). Effect of sex and sub-zero storage temperature on the microbial and oxidative stability of pig packed in a high-oxygen atmosphere after different vacuum 
ageing times. Meat Sci., 148, 198-205. doi: 10.1016/j.meatsci.2018.09.005.

Juárez, M., Caine, W.R., Dugan, M.E., Hidiroglou, N., Larsen, I.L., Uttaro, B., \& Aalhus, J.L. (2011). Effects of dry-ageing on pork quality characteristics in different genotypes. Meat Sci., 88(1), 117-121. doi: 10.1016/j.meatsci.2010.12.011.

Klauke, T.N., Piñeiro, M., Schulze-Geisthövel, S., Plattes, S., Selhorst, T., \& Petersen, B. (2013). Coherence of animal health, welfare and carcass quality in pork production chains. Meat Sci., 95(3), 704-811. doi: 10.1016/j.meatsci.2013.03.022.

Li, Y.X., Cabling, M.M., Kang, H.S., Kim, T.S., Yeom, S.C., Sohn, Y.G., Kim, S.H., Nam, K.C., \& Seo, K.S. (2013). Comparison and correlation analysis of different Swine breeds meat quality. Asian-Australas J Anim Sci, 26(7), 905-910. doi: 10.5713/ajas.2012.12622.

Misik, A.T. (2014). Stan ta napryamky rozvytku svynarstva [Status and trends of pig breeding]. Svynarstvo, 65, 8-14 (in Ukrainian).

Nassu, R.T., Tullio, R.R., Berndt, A., Francisco, V.C., Diesel, T.A., \& Alencar, M.M. (2017). Effect of the genetic group, production system and sex on the meat quality and sensory traits of beef from crossbred animals. Trop Anim Health Prod., 49(6), 1289-1294. doi: 10.1007/s11250-017-1327-3.

Pauly, C., Luginbühl. W., Ampuero, S., \& Bee, G. (2012). Expected effects on carcass and pork quality when surgical castration is omitted--results of a metaanalysis study. Meat Sci., 92(4), 858-62. doi: 10.1016/j.meatsci.2012.06.007.

Plohinskij, N.A. (1969). Rukovodstvo po biometrii dlja zootehnikov [Guide for biometrics for livestock]. M. Kolos (in Russian).

Polivoda, A.M. (1976). Ocinka jakosti svynyny za fizykohimichnymy pokaznykamy [Assessment of pork quality by physical and chemical indices]. Svynarstvo, 24, 57-61 (in Ukrainian).

Sánchez-Macías, D., Barba-Maggi, L, Morales-delaNuez, A., \& Palmay-Paredes, J. (2018), Guinea pig for meat production. A systematic review of factors affecting the production, carcass and meat quality. Meat Sci., 143, 165-176. doi: 10.1016/j.meatsci.2018.05.004.

Shavaljuk, O., \& Popivnjak, R. (2014). Svinarstvo jak efektivna galuz' prodovol'chogo kompleksu Ukraïni [Pork as an effective branch of Ukraine's food complex]. Visnyk L'vivs'kogo nacional'nogo agrarnogo universitetu. Serija: Ekonomika APK, 21(1), 357-360 (in Ukrainian).

Strizhak, T.A. (2014). Vidgodivel'ni m'jasni oznaky svinej porodi landras vitchyznjanoi ta importnoi selekcii pry chystoporodnomu rozvedennju [Fodder and Meat Characteristics of Landrace Porcine Domestic and Imported Selection for pure breeding]. Naukovo-tehnichnij bjuleten' IT NAAN, 112, 139143 (in Ukrainian).

Topiha, V.S. (2014), Poroda landras, ii adaptacijni ta produktyvni jakosti v umovah promyslovoi tehnologii [The species Landrace, its adaptive and productive qualities in terms of industrial technology]. Naukovotehnichnyi bjuleten, 112, 150-159 (in Ukrainian).

Topiha, V.S. ta inshi. (2008). M'jasni genotypy svynej pivdennogo regionu Ukrainy. [Meat genotypes of pigs in the southern region of Ukraine]. Mikolaiv: MDAU (in Ukrainian).

Tsereniuk, O.M., Akimov, O.V., Tymofiienko, I.M., \& Chereuta, Yu.V. (2016). Suchasni aspekty rozvedennia svynei porid landras ta uels v Ukraini. Naukovotekhnichnyi biuleten, 115, 227-236. Rezhym dostupu: http://nbuv.gov.ua/UJRN/Ntb_2016_115_38 (in Ukrainian).

Vojtenko, S.L. (2015). Produktivnist' svinej porodi landras [Productivity of Landrace Pigs]. Visnik agrarnoï nauki Prichornomor'ja, 1, 171-179 (in Ukrainian).

Voloshhuk, V.M. (2013). Vidgodivel'ni ta m'jasni jakosti svynej riznyh selekcijnyh stad $\mathrm{v}$ umovah stancii kontrol'noi vidgodivli Institutu svynarstva i APV NAAN Ukrainy [Feed and meat qualities of pigs of different breeding herds in the conditions of the control fattening plant of the Institute of pig breeding and poultry farming of the National Academy of Sciences of Ukraine]. Bjuleten' Institutu sil's'kogo gospodarstva stepovoï zoni, 4, 142-152 (in Ukrainian). 